\title{
CHAOS THEORY AS DEPICTED IN THE ADJUSTMENT BUREAU
}

\author{
Laliyah Khairun Novia and Nurenzia Yannuar \\ laliyahknovia@gmail.com,nurenzia.yannuar.fs@um.ac.id \\ English Department, Faculty of Letters, State University of \\ Malang, Indonesia
}

\begin{abstract}
The Adjustment Bureau movie is an example of how Chaos Theory, a theory originated from Physics, can be applied in a work of popular cultural product. This paper analyzes how Chaos Theory's Butterfly Effect, in which one small event brings significant effects, presents in events affecting David Norris' future life. The paper firstly discloses the main character's (David Norris) life as determined by the Bureau. It then focuses on how slight mistakes change the supposed outcome of his life. Lastly, chaos leads to the compatibilist idea proposing the reconciliation of Determinism and Free Will.
\end{abstract}

Key words: chaos theory, the butterfly effect, sensitive dependence on initial conditions, determinism

Abstrak: Film The Adjustment Bureau adalah salah satu contoh bahwa teori yang berkembang dalam ilmu Fisika dapat diterapkan untuk menganalisis suatu karya yang merupakan produk budaya populer. Penelitian ini berusaha untuk mengungkapkan bagaimana salah satu teori Chaos, yaitu Butterfly Effect atau Efek Kupu-Kupu, yang menyatakan bahwa satu kejadian kecil dapat memberikan efek signifikan di masa depan, hadir dalam kehidupan David Norris, sebagai karakter utama dalam film ini. Pertama, penelitian inidifokuskan pada kehidupan David Norris sebagaimana ditentukan oleh sang Bureau. Kemudianpenelitian dilanjutkan dengan mempelajari bagaimana satu kesalahan kecil mampu mengubah masa depan yang telah direncanakan sebelumnya. Terakhir adalah penerapan teori Chaos pada film ini yang membawa kita pada ide compatibilist, yang menyarankan adanya rekonsiliasi antaraDeterminisme dan Kehendak Bebas. 
Kata kunci: teori chaos, efek kupu-kupu, determinisme, kehendak bebas

\section{INTRODUCTION}

During the seventeenth and eighteenth centuries, classical scientists suggested that our universe was a huge deterministic system since the discovery of Newtonian laws. Nevertheless, this view gradually shifted after some scientists found that Newtonian mechanics were not always accurate to calculate the outcome of a system (Maxwell, 1925; Poincare in Davies, 1999; Carnot in Velasquéz, 2009; Einstein in Pritzker, 2011). Started from the Second Law of Thermodynamics, Quantum Mechanics and the Butterfly Effect, these scientists believed that our universe was likely to exist more in disorder and random. Chaos Theory describes a system which apparently lacks order and predictability. There is sensitive dependence on initial conditions that can affect the possible outcome of a system on large scale phenomenally declares that the flapping of a single butterfly's wing today produces a tiny change in the state of the atmosphere. Over a period of time, what the atmosphere actually does diverges from what it would have done. So, in a month's time, a tornado that would have devastated the Indonesian coast doesn't happen, or maybe one that wasn't going to happen does (1989, p. 141). This phenomenon explains the foundation of Chaos Theory as a new science that describes one small change in the initial conditions can drastically change a stable structured system. Due to the popularity of interdisciplinary field in today's academic activity, Chaos Theory now can be used not only in exact scientific research, but also in the field of social studies.

The Adjustment Bureau is a 2011 American movie, directed by George Nolfi, which features Matt Damon and Emily Blunt in leading roles. This 1hour-and-46-minute movie is adapted from one of Philip K. Dick's short stories of the same title, Adjustment Team. It narrates the struggle of a New York State senator candidate, David Norris, in pursuing the only woman he loves, Elise Sellas. He fights against a mysterious Bureau that keeps them apart. Apparently, this Bureau is in charge to watch David's every single move to comply witha plan written by the Chairman. Yet, the initial plan is threatened to have an enormous change because of one slight mistake that David's proctor, Harry Mitchell, commits unintentionally during the mission. 
This movie delivers the principles of Chaos Theory, particularly the Butterfly Effect, in which even one small occurrence can result in large consequences. The Adjustment Bureau includes chaos in David's determined life as a system. Therefore, this article is divided into two main parts: the initial conditions of David Norris' life and the emergence of chaos in it.

\section{INITIAL CONDITIONS OF DAVID NORRIS’ LIFE}

To begin the analysis of how chaotic David Norris' life is, it is important to discuss his life plan as determined by the Adjustment Bureau as a whole system. This is important in order to have clear picture of the presumed outcome of the initial state of David's life. Determinism theory is employed to reveal the series of events that are intended to be David's initial life. In essence, determinism is "the doctrine that every event is shaped down to the last detail by a prior set of events and conditions" (Drakopoulus \& Torrance, 1994, p. 176).

\section{A. Unhappy Childhood}

The early stage of humans is a very important phase due to its influence on the outcome of the grown-up phase. The condition of family, friends and society hassignificant function in shaping someone's personality. This also happens to David Norris who experienced series of unfortunate events when he was a kid. He lost his beloved father, mother and brother at such a young age. These all-miserable scripted stories by the Bureau exhibit one obvious purpose: to put David in emptiness. Emptiness in his life will drive him to re-value his own existence. Because of his father and a promise to his brother, he can find the answer to fill up the emptiness by becoming a politician. He knows he can do better than his brother by following John F. Kennedy's path, which supposedly could make his father proud. This is the first plan that the Bureau designs in order for David to show him the path where he belongs.

\section{B. Impulsive Adolescence}

The family dysfunction that David Norris faced in childhood has left a serious wound that affects his behavior as an adult. Adolescence is a transitional period during which a child is becoming, but is not yet, an adult (Ortiz, 2004, para. 2). This stage begins and ends around 11-21 years old; during this time a person has to deal with some changes on their emotions, 
hormones, judgment, identity and physical body. David, as a normal human being, cannot escape from this transitional period; thus it triggers the Bureau to create another cause for his 'political future effect'. Hence, this time, the plot still places him in a negative position where he needs to be a delinquent teenager before winning the public's love.

When he tells Elise about his childhood after clubbing, he reveals that he spent about half his time in the principal's office up until the sixth grade which means at that time he was in his early stage of adolescence. Ending up in the principal's office frequently clearly indicates how delinquent he was. If a student's misbehavior is often brought to the principal, it shows how serious they have violated school regulations.

The death of his father before he got to high school does not stop him from doing reckless and impulsive things. The immature action continues as he enters high school. This is discovered when David tells Elise when they meet for the first time in Waldorf men's room:

David: "I crashed a wedding once. Yeah, in high school. But I got caught. I spent the night in jail" (Nolfi, 2011, 00:08:20 - 00:08: 27).

Back then David had the same situation as Elise who also committed this small crime. Though he already had a dream to be a politician, he kept acting impulsive without noticing the bad impact that he will receive when he pursues his political career.

\section{Adulthood and Upside-Down Political Career}

When David was 24 years old, he became the youngest person ever elected to the House of Representative. It is quite unbelievable considering his dark adolescence when he often ended up in principal's office. But then, he got involved in a bar room fight the night that he was elected which indicates that his impulsiveness still haunts him and becomes the hardest obstacle that he must overcome.

The bar brawl has already destroyed his first attempt to enter the House of Representative. There is also a photo released by the New York Post that destroys his dream again while doing his campaigns for the-2006election. The photo pictures him doing prank in college reunion which once again shows his immaturity. Even though he recently is way ahead in the polls, he cannot escape from the reality that people do not like this childish behavior. 
David's impulsiveness somehow indicates that humans unavoidably hold free will. Humans' actions cannot entirely be determined by the Bureau, becausemost of the time they act consciously. It is proven by how Thompson, a higher-ranking member of the Bureau, blames David for acting impulsively. Thompson blames David for being reckless. In fact, he does not blame the Bureau members who are responsible for David's plan like Harry or Richardson, but David himself. This means that the Bureau cannot fully control every human plan since they actually possess 'self entity' to decide what step they are going to take. Alas, David's 'free' actions do not guard him to a bright future, but a dark one. Therefore, they fix it with some great failures and embarrassing moments to pump his determination for being a better person.

After this the current failure of being a New York congressman makes the Bureau work harder to write a plot that causes him to be the front runner in the next election. Therefore, they decide to put Elise Sellas, a contemporary ballet dancer, in the middle of David's crisis. The Bureau is aware of Elise's outstanding personality that could give David enlightenment to create a brilliant speech that will make him the front-runner of the upcoming election. However, this decision is also a fatal mistake since it can be seen as David's turning point of a whirlwind romance.

\section{Possibility of Romance}

David's love life story is quite different from his political move. The Bureau evidently directs his fate to victory, although he has to battle with some failures before it. On the other hand, his romantic life is hard to achieve as planned by the Bureau. It appearsthat they do not want to occupy David's emptiness with some sexual desire, but with public's applaud instead. Harry explains this to David, "Because she's enough, David. If you have her, you won't need to fill that void inside of you with applause and votes and dreams of one day making it to the White House" (Nolfi, 2011, 01:17:29 01:17:40). The only reason the Bureau posits Elise Sellas into David's sorrowful day is just because she is an inspirational person that can light up someone right away.

A month after losing the 2006 Senate election, the Bureau manages David to work in RSR venture capital company founded by his childhood friend as well as his campaign chairman, Charlie Traynor. That morning on that particular day, David is deliberated to be Charlie's current partner to coax investors who would like to invest their money on the Solar Panel 
project. Therefore, observing the Bureau's original plan, there is no 'romance' possibility within his life since he needs to focus on rebuilding his image and later pursuing the election again. Elise is planned to be forgotten by him, although the Bureau knows howsexually attracted David is to her.

\section{E. Presumed Outcome}

The presumed outcome of this whole system is that the Bureau wants David to be the president of United States. Thompson said that:

Thompson: "This one and four more after it. And I'm not just talking about elections about for Senate. You can matter, David. Really matter. [...] the president can't be loose cannon" (Nolfi, 2011, 01:05:27 - 01:06:28).

Althoughit does not happen yet, it is stated that David is actually a potential presidential candidate after winning five Senate elections in the future. They know David can matter, for he is capable of leading a big country like the United States. People will definitely favor him through his sincerity and honesty. This is what the Bureau wants as they began designing the initial state of his life. After struggling with so many obstacles that the Bureau gave, David eventually will make it to the White House.

\section{THE EMERGENCE OF CHAOS}

The behavior of David Norris' life system is drastically changed by two small causes on the initial conditions. The first one is Harry's slight mistake during the proctorship on David, and secondly the presence of chances that unpredictably appears to him in spite of the separation the Bureau creates.

Chance refers to an event of which the cause is unidentified or unknown (deRond, 2004). This movie contains a lot of causality significance based on what David has faced. He wanted to become a politician because of his father; he lost the first election as people witness him fighting in a bar; and then he also lost the 2010 Senate race due to an embarrassing picture; there is always the exact prior event (cause) that results in the exact new event (effect). The first chance that the Bureau needs to handle regarding David's designed plan is the death of his mother. His father and brother leave him as signified by the plan, but his mother does not. His mother's case is unexpected and unknown, thus it is purely a chance. Luckily, this incident 
does not really affect David's initial designed plan. But the question is how about the other chances?

\section{A. Harry's Misconduct on the Mission}

The plan instructs David to work in Charlie's venture capital company, RSR, a month after the failure of 2006 Senate election. That morning Harry Mitchell is assigned to ensure David spill his coffee as soon as he enters the park at 7.05 AM. Why is this event very important? There are two significances concerning this matter. First, his path through the world that morning is supposed to be adjusted and David should not see the adjustment motion. Secondly, he is not supposed to encounter Elise again since the plan clearly mentions they are not meant to be together.

The Bureau has to do several adjustments concerning the Solar Panel investment that Charlie's company has been working on. This idea actually comes from David who sees energy efficiency opportunity with Solar Panel.Charlie is against it because the price is too high. Therefore, the Bureau's Intervention Team led by Richardson comes to Charlie's office to recalibrate his mind for David so that they can work as partners. Due to this reason, it is very important for Harry to do his job properly. If David spilled his coffee on his shirt, he would miss the bus, he would arrive at work late, and at last Charlie whould have agreed on the project. Unfortunely, Harry falls asleep and ruins the plan. David is eventually able to catch up the 'bus' and witness the Bureau's existence.

\section{B. Reunion with Elise}

The unexpected chance not only brings him to the revelation of the Bureau existence, but also to Elise for the second time. This chance to some extent offers David and Elise an opportunity to outgrow their feelings toward each other whichleads the Bureau to a 'nightmare'. It is called a nightmare because the Bureau is having such a bad luck after the reunion. The strong chemistry between David and Elise defeats the Bureau's ripple power. David eventually has Elise's phone number due to Harry's ripple that makes him spill the coffee on her skirt. Therefore, he asks her to write her number in case he needs to pick up that skirtfrom the laundryand indeed it is one of his ways to get closer to her. Instead of being an obstacle, the ripple seemingly turns out to be an advantage for this couple, for they can learn about each other. 
The Bureau's decision to burn Elise's number shows their assumption as if everything could return to their initial plan, but the fact is they are wrong. In fact, this system is more random and disordered because David's affection to Elise is too strong. Despite the Bureau's success in separating and keeping them apart on a three-year plan, the chaos still remains, as David never gives up looking for her.

\section{Bumping into Elise after the Three-Year Separation}

Riding the same bus to go to work for three years is the best and only way that David can try in order to meet Elise again. He even takes the same seat as Elise when he first saw her on the bus. He knows that the Bureau will not let him reach her, yet the chance possibly will. And unbelievably, he finally has the chance. He spots Elise walking on the street while he is on that special bus. This second reunion makes their relationship stronger than before because they successfully spend time together regardless of dozens of ripples that Richardson, Harry's boss, creates during the race between David and him.

\section{The Bureau's Unawarenessof David's Earlier Plan}

The subtlest root of the chaotic behavior in David Norris' plan is their unawareness of his earlier version plan. This is the actual ground of all the following variations that may turn into a complexity. After the failure of the 2006 Senate election, Harry Mitchell as David's case officer undoubtedly places Elise in the middle of David's dark days in order to enlighten him. But the problem is that he does not have any idea that this decision turns out to be a boomerang for the Bureau itself.

The old plan indicates that David and Elise were actually meant to be together, which isthe opposite of the new version of his plan. From the day he was born, they were written to be a couple. However, without any exact reason, the Chairman decided to change it in 2005 and Elise was supposed to stay with Adrian Troussant, a dance choreographer. Unfortunately, Harry does not know this piece of information due to his lower position in the Bureau; so he cannot enter some kind of 'fate library' to check whether inserting Elise in David's life is the correct decision or not. But the funniest part is that even higher-ranking members like Donaldson and Burdensky who can access the library are also unaware about David's changing plan. Therefore, it portrays the Bureau's clumsiness, which has becomethe source of all the events above. 


\section{E. Sensitive Dependence on David's Initial Conditions}

Sensitive dependence is a scientific term in chaos theory that defines unpredictability in a system. In fact, sensitivity to initial conditions is the chief source of that unpredictability because it is the main way in which you can recognize a chaotic system (Loy, 1997). We have already observed how small variations in David's initial plan change the stability of its system. They create more random and chaotic behavior that affects the possible outcome of this system.

Afraid that there would be serious effects on David's possible outcome, the Bureau appoints Thompson to clean up this mess. Thompson organizes a secret meeting with David in order to persuade him after appearing in The Daily Show program. He tries to reason with David about the effects of these rebellions to the presumed outcome of his fate. He lets David see his future in which he could be a potential presidential candidate of the United States. The Bureau believes in him that he can change the world and according to the plan, it will not happen if he stays with Elise. But this persuasion is all in vain because David does not care much about this and still insists on choosing Elise over anything. But then, David ultimately withdraws his decision after Thompson exposes Elise's unfavorable future if they are together. We can know that there would be sensitivity not only to David's initial plan but also to Elise's. Providing David insisted on ignoring his initial plan, the obvious sensitivity that he received was giving up the opportunity to be president. The worst part is that Elise would end up being a dance teacher for six-year-old kids. That is why it is very important for the Bureau to keep them on the plan, for they can matter on their own fields. David could be a great influential president of the United States while Elise could be a great influential dance choreographer. They can change the world together when they are not together.

Although the potential sensitive dependence is not depicted to happen in this movie, but at least we have the vision of how chaotic it would be if David and Elise kept violating the plan. They both would end up being 'nothing' despite their talents or gifts. Provided that David did not become the President of the United States, but other politicians made it, then what would happen? There is a possibility that Roger Linfield, the winner of 2006 Senate election, will be the president. As a result, America is going to be led by a 'tool', which means that he is not as capable as David in running the government. 
Elise: "Are you going to run again?"

David: "Don't know, I'm starting a new job today."

Elise: "You have to run again. You can't do that. The country will end up being run by tools like Linfield."

David: "It kind of is" (Nolfi, 2011, 00:18:38 - 00:18:48).

According to Elise and David, Linfield's inability to run this big and powerful country will eventually affect other people's lives. David will work on Solar Panel project to change the world into a better one, but what about Linfield? There is no guarantee that he can make decisions and actions without being controlled by others because he is an incompetent leader.

\section{F. Hidden Order}

The final story of David's plot brings us to the second definition of Chaos Theory stating that the randomness and disorder of a chaotic system does contain order which exists in a nonlinear form (Ward, 1996). The ending of the movie shows that David eventually is able to knock down the Bureau with some help from Harry Mitchells. He teaches David about their hat which is a tool to teleport with doors. Fearlessly, David crosses through the town to reach Elise who is nearly getting married to Adrian Troussant. He dares to take a risk by revealing the Bureau's existence to convince Elise that he terribly loves her. Without any doubt, he asks her to come with him to meet the Chairman. Surprisingly, David's risky determination has inspired the Chairman to write a new plan for them: they are meant to be together.

With the presence of total randomness, this movie shows that Chaos Theory indicates an area where it is a complete order. David's success in changing his fate after doing endless rebellions indirectly leads the viewers to the fact that the chaotic system performs a new orderly one. And the most remarkable thing is that his new plan goes back to his earlier initial condition where the Chairman sets him up to stay with Elise. Besides, the comparison between the books of David's original plan and his new plan gives a clue that David still has the opportunity to be President. David's new plan book proves that he can choose his own way because the rest of its sheet is still left blank. After these chaotic behaviors in his life, David might perform to return to his initial condition where he is destined to be the President. This might happen to Elise as well since both their inflection points are walking together side by side indicating that Elise still has a chance to be one of the world's greatest dancer and choreographer. 


\section{G. Chaos Leads to Compatibilism}

Compatibilism states that reconciliation between determinism and freedom of choice is possible after all because we have an experience of freedom when choosing (deRond, 2004). The implication of compatibilism in this movie is reinforced by the depiction of a chaotic system in David's life. Before getting involved with the Bureau, David's life seems very normal and smooth. He acts as every single day comes and goes because that is the way the world is. He has no idea about the existence of the Chairman and theBureau which influences his decision even though it is just a small one like picking the bus to go to work. Then his life is drastically changed after finding out the truth about how the world works. Starting from here, we can grasp the strong suggestion of compatibilist issue.

First, it is the existence of the Bureau itself. If it is all determined, why does the Chairman need the Bureau to keep the people stay ontrack? This Bureau has innumerable workers who are charged to guide people to follow the fate that has been written for them. They do not write the initial condition, but they are just case workers whose job is to ensure that everything adheres to the plan. Therefore, the Bureau itself unintentionally indicates that the Chairman cannot deny humans' conscious decision that can change their original plan. The Chairman might be the one who creates human's fate, but humans also possess free will to decide where they want to go. This movie tries to show the viewers how hard it is to claim that this universe is fully determined since the humanity is too complex to predict.

Secondly, the presence of recalibration action that the Bureau performs to Charlie Traynor shows that total freedom is also not suitable for humanity since it could bring destruction. As Harry explains why they have to interfere with Charlie's judgment on Solar Panel investment, we can get the idea that free will is not a proper theory to describe the complexity of world.

The last interpretation from this movie that indicates compatibilist idea is the last scene which pictures David and Elise walking on the street along with some workers of the Adjustment Bureau, including Harry. The scene discloses what the movie tries to say about the determinism and free will debate. After the chaotic system in David's life, the reconciliation between these opposite theories is possible. We can seize the impression through the portrayal of humans and the Adjustment Bureau scattered on the street simultaneously. David and Elise represent free will as they finally 
fulfill their fate with their own will while Harry and the police holding the book fate speak for determinism.

At last, David's chaotic system implicitly leads the viewers to the development of Chaos Theory as a scientific revolution. The gradual presence of Chaos Theory among the ultimate deterministic classical scientific theories really helps people to understand more about the randomness of our universe, and The Adjustment Bureau, as a popular cultural product, embodies the agreement on compatibilist idea to redefine our universe and the rest of humanity through David's portrayal as he is not scared to fight for his free will to determine his own final path or presumed outcome as a part of a deterministic system. But then again, the Bureau cannot abandon humans with total freedom since this world would turn into chaos if the Bureau did not interfere in determining humans' lives.

\section{CONCLUSION}

The Adjustment Bureau is a movie demonstrating how one can attempt to analyze work of literature using scientific theory. Using Chaos Theory turns out to be helpful to reveal the chaotic system in David's determined life after the occurrence of one small unintentional mistake. This idea is the core of Chaos Theory, in which one slight unforeseen event in a system can result in massive errors. Thus being said, David's plot story as the whole system is a perfect example in creating a comprehensive depiction on how Chaos Theory works.

In this movie, David is pictured as a young ambitious politician whose life is under the control of the Adjustment Bureau. The Bureau ensures David's life adheres to the fate that the Chairman has written for David. Through the series of events the Bureau has created for David, he is expected to be President of the United States since they believe David can change the world into a better one. However, this future is threatened to change due to the small mistake that Harry, David's proctor, does during the mission. Because of this, David reunites with Elise, a woman he has a crush on after their captivating meeting in Waldorf men's room where David practices his concession speech. The problem is that he is not supposed to be with her as the Bureau made it so. Hence, if he continues choosing Elise, he might lose the opportunity of being a president. Chaotic behavior in David's life inevitably creates a new ordered system in its own way. In the end of this movie, David can change his fate owing to some rebellious actions he does 
while pursuing it. Therefore, it leads to a conclusion related to the second definition of Chaos Theory, which states that randomness and disorder in chaotic system bear order instead. It performs a new system for David's life in which he finally achieves his dream to be with Elise.

Finally, the emergence of chaos in David's life proves that compatibilism is the most suitable theory to describe the complexity of our universe. The movie portrays the possibility of reconciliation between determinism and free will through the existence of the Bureau, the recalibration activity, and the last scene's interpretation. The Bureau stands for Determinism, since this organization control every human's life to adhere to the plan, written by the Chairman. However, the Bureau also cannot deny the fact that humans possess free will and this becomes the reason why they have to perform recalibration to adjust a plan. The last scene which presents David and Elise walking together with the Bureau workers scattering around the road implies the idea of compatibilism.

\section{REFERENCES}

Stewart, I. (1989). Does God Play Dice: The New Mathematics of Chaos. UK: Blackwell Publishing.

Drakopoulos, A. T. (1994). Causality and Determinism in Economics. Scottish Journal of Political Economy, 41.

Ortiz, A. (2004). Adolescence, Brain Development, and Legal Culpability. Juvenile Justice Center.

Nolfi, G. (Director). (2011). The Adjustment Bureau [Motion Picture].

deRond, M. T.-A. (2004). Chance, Choice and Determinism in Strategy. Judge Institute of Management: University of Cambridge .

Loy, J. (1997). Chaos - Sensitivity to Initial Conditions. Retrieved November 11, 2013, from Jimloy: http://www.jimloy.com/fractals/chaos.htm

Ward, B. (1996). The Chaos of Theory: Notes Towards a Postmodernist Historiography. Limina, 2.

Davies, B. (1999). Exploring Chaos: Theory and Experiment. Massachusetts: Perseus Books. 
14 Celt, Volume 15, Number 1, July 2015, pp. 1-14

Maxwell, J. (1925). Matter and Motion. London: The Sheldon Press.

Pritzker, C. (2011). Tom Stoppard: Humanizing Chaos. Miami, Florida: FIU Electronic Theses and Dissertations.

Velasquéz, T. (2009). Chaos Theory and The Science of Fractals, and Their Application in Risk Management. Copenhagen Business School.

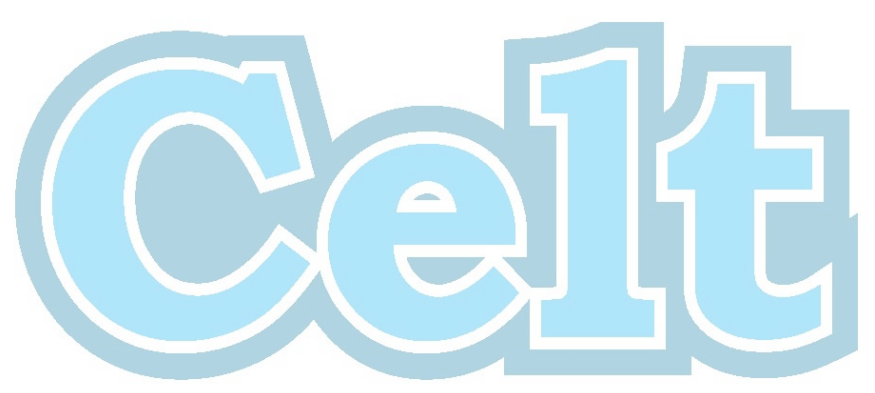

